\title{
Dynamic Rupture Modeling of the Transition from Thrust to Strike-Slip Motion in the 2002 Denali Fault Earthquake, Alaska
}

\author{
by Brad T. Aagaard, Greg Anderson, and Ken W. Hudnut
}

\begin{abstract}
We use three-dimensional dynamic (spontaneous) rupture models to investigate the nearly simultaneous ruptures of the Susitna Glacier thrust fault and the Denali strike-slip fault. With the $1957 M_{\mathrm{w}} 8.3$ Gobi-Altay, Mongolia, earthquake as the only other well-documented case of significant, nearly simultaneous rupture of both thrust and strike-slip faults, this feature of the 2002 Denali fault earthquake provides a unique opportunity to investigate the mechanisms responsible for development of these large, complex events. We find that the geometry of the faults and the orientation of the regional stress field caused slip on the Susitna Glacier fault to load the Denali fault. Several different stress orientations with oblique right-lateral motion on the Susitna Glacier fault replicate the triggering of rupture on the Denali fault about $10 \mathrm{sec}$ after the rupture nucleates on the Susitna Glacier fault. However, generating slip directions compatible with measured surface offsets and kinematic source inversions requires perturbing the stress orientation from that determined with focal mechanisms of regional events. Adjusting the vertical component of the principal stress tensor for the regional stress field so that it is more consistent with a mixture of strike-slip and reverse faulting significantly improves the fit of the sliprake angles to the data. Rotating the maximum horizontal compressive stress direction westward appears to improve the fit even further.
\end{abstract}

\section{Introduction}

The 3 November 2002 Denali fault earthquake was a complex $M_{\mathrm{w}} 7.9$ event with rupture beginning on the Susitna Glacier thrust fault, continuing onto the Denali strike-slip fault, and terminating on the Totschunda strike-slip fault (Eberhart-Phillips et al., 2003). Figure 1a shows the location of the surface rupture. Other earthquakes have displayed behavior similar to the transition of rupture from the Denali fault to the Totschunda fault, with strike-slip rupture jumping gaps between or branching across nearly vertical segments in the 1979 Imperial Valley, California (Archuleta, 1984), 1992 Landers, California (Johnson et al., 1994; Sowers et al., 1994), 1999 Kocaeli (Izmit), Turkey (Lettis et al., 2002), and 1999 Hector Mine, California (Treiman et al., 2002) earthquakes. However, only one other welldocumented large continental earthquake clearly involved approximately simultaneous substantial thrust and strike-slip rupture. The $1957 M_{\mathrm{w}} 8.3$ Gobi-Altay, Mongolia, mainshock involved significant slip on both the Bogd strike-slip fault and the Gurvan Bulag thrust fault (Florensov and Solonenko, 1965; Bayarsayhan et al., 1996; Kurushin et al., 1997; Prentice et al., 2002). The sequence of rupture is not known, but either is consistent with static-stress-transfer modeling $(\mathrm{Ku}-$ rushin et al., 1997).
These numerous examples of multisegment and branching ruptures across strike-slip faults have inspired numerous numerical analyses of similar geometry. Many studies have focused on the role of fault geometry (e.g., Harris et al., 1991; Harris and Day, 1993; Kase and Kuge, 1998, 2001; Oglesby et al., 2003a), whereas others have focused on specific events. Olsen et al. (1997), Harris and Day (1999), and Aochi and Fukuyama (2002) sought to explain the propagation of rupture across various portions of the Johnson Valley, Kickapoo, Homestead Valley, Emerson, and Camp Rock faults in the 1992 Landers, California, earthquake. Harris et al. (2002) showed ruptures could jump across stepovers of a few kilometers, which explained the ability of the 1999 Kocaeli rupture to bridge the step-overs between the Gölcük, Sapanca, Sakarya, and Karadere segments but not to jump onto the Karadere and Düzce segments. Oglesby et al. (2003b) demonstrated that the absence of surface rupture on the northeast branch of the Lavic Lake fault in the 1999 Hector Mine earthquake allowed slow rupture to occur on the northwest branch. In general, these studies as well as parametric studies with generic strike-slip faults (e.g., Aochi et al., 2000; Poliakov et al., 2002; Kame et al., 2003) indicate that the level and orientation of the stress fields and the speed of the rupture as it encounters a segment boundary are 


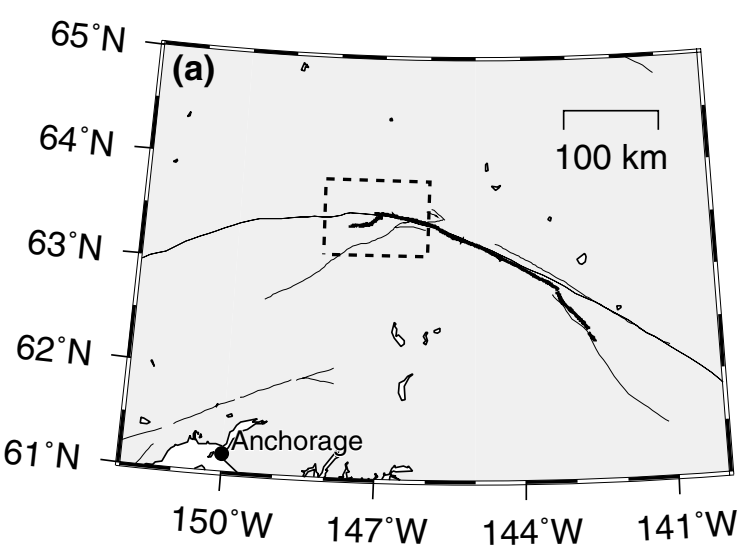

(c)

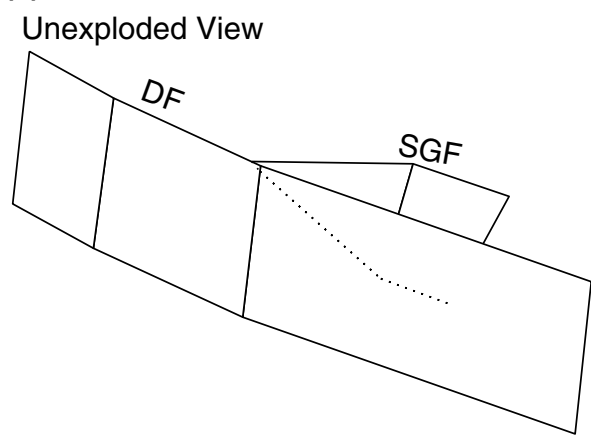

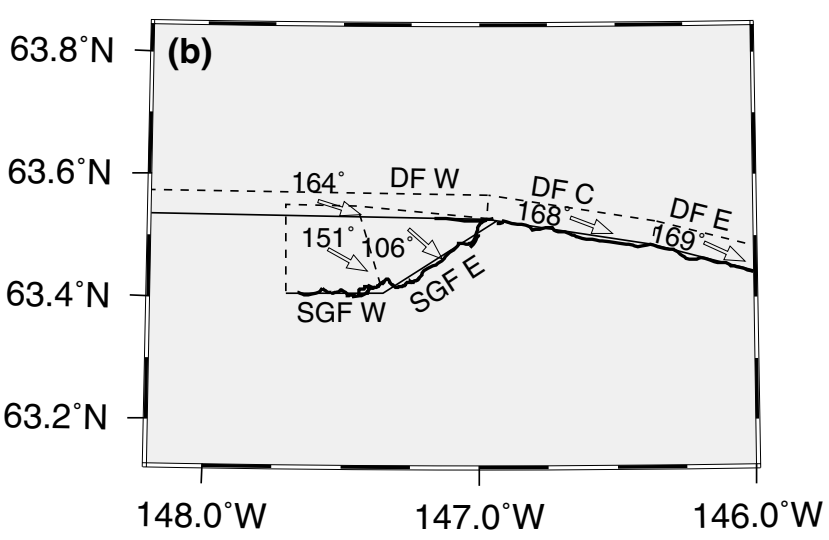

Exploded View

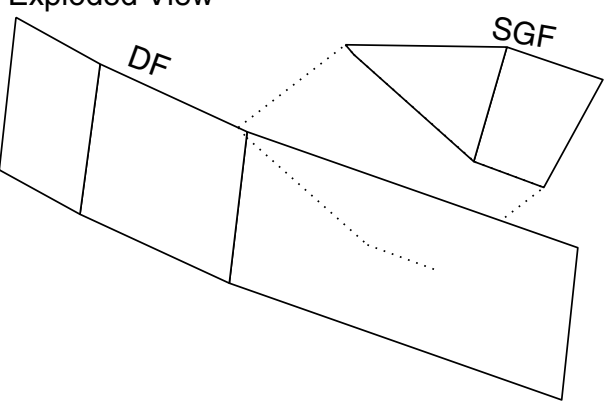

Figure 1. (a) Location of Denali fault rupture (thick lines) and simulation region (dashed lines) (shown in b). The thin lines delineate surface traces of major faults. (b) Surface rupture (thick lines), simulation fault geometry (thin solid and dashed lines; see Table 2), and shear-stress orientation (arrows) on each segment for scenario Rd (see Table 3). (c) Unexploded and exploded views of the fault surfaces as viewed from the northwest.

two important factors that control whether a rupture will continue propagating beyond complex junctions.

Learning when earthquakes will or will not jump from one fault strand to another is important for constraining the physics of the rupture process and understanding the seismic hazard. With all these issues in mind, we focus on the first and more unusual transition of rupture in the 2002 Denali fault earthquake, that from the Susitna Glacier fault, with right-lateral oblique motion, to the Denali fault with its predominantly right-lateral strike-slip motion. We seek the simplest explanation of this transition with our threedimensional finite-element models, in particular, whether the transition can be explained by fault geometry and stress orientation alone. This work has also served as a stepping stone for considering whether similar complex rupture transitions could occur in southern California, between the Sierra Madre/Cucamonga thrust system and the San Andreas and San Jacinto strike-slip systems (Anderson et al., 2003).

\section{Methodology}

We model a 110-km-long, 80-km-wide, and 40-kmdeep region surrounding the Susitna Glacier and Denali faults as illustrated in Figure 1a. We discretize the region using tetrahedral finite elements with dislocations across the fault surface created using split nodes. This technique is particularly well suited for modeling complex geometry with the element size following variations in the shear-wave speed. Aagaard (1999) and Aagaard et al. (2001) discuss the details of this dynamic (spontaneous) rupture modeling technique, which solves the three-dimensional dynamic elasticity equation, incorporating the physics of fracture and slip on fault surfaces through friction models, to produce time histories of fault slip and deformation within the volume.

Figure 2 and Table 1 give the piecewise linear variations in the material properties with depth that are based on the uniform layered model Crust 2.0 (Bassin et al., 2000). We select a discretization size of 10-12 nodes per shear wavelength (this corresponds to element edges of 570-750 m) that allows accurate modeling of seismic waves with periods of $2.0 \mathrm{sec}$ and longer.

We approximate the geometry of the fault surfaces with five planar surfaces that closely follow the mapped surface rupture (Fig. 1b). Because the down-dip geometry of the Susitna Glacier fault is poorly determined, we choose a uniform dip angle of $35^{\circ}$ that closely matches a kinematic 

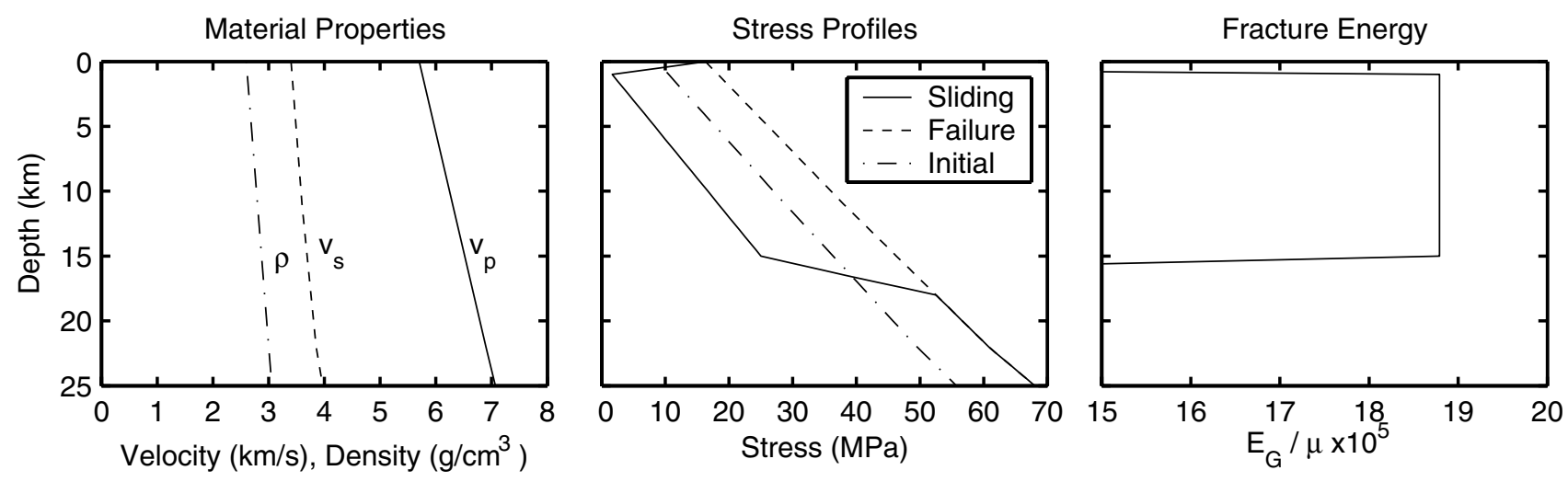

Figure 2. Material properties (a), shear stresses (b), and fracture energy (c) as a function of depth. (a) The shear-wave speed $\left(v_{s}\right)$, dilatational wave speed $\left(v_{p}\right)$, and mass density $(\rho)$ define the material properties. (b) Magnitude of the initial shear stress, frictional sliding stress, and frictional failure stress. (c) Fracture energy $\left(E_{G}\right)$ normalized by the shear modulus.

Table 1

Material Properties

\begin{tabular}{cccc}
\hline $\begin{array}{c}\text { Depth } \\
(\mathrm{km})\end{array}$ & $\begin{array}{c}\text { Mass Density } \\
\left(\mathrm{kg} / \mathrm{m}^{3}\right)\end{array}$ & $\begin{array}{c}\text { Dilatational Wave Speed } \\
(\mathrm{km} / \mathrm{sec})\end{array}$ & $\begin{array}{c}\text { Shear-Wave Speed } \\
(\mathrm{km} / \mathrm{sec})\end{array}$ \\
\hline 0 & 2600 & 5.70 & 3.40 \\
11.0 & 2800 & 6.30 & 3.60 \\
22.0 & 3000 & 6.90 & 3.85 \\
38.0 & 2300 & 7.80 & 4.50 \\
40.0 & 3300 & 7.80 & 4.50 \\
\hline
\end{tabular}

Control points describing linear variation of material properties with depth. The material properties are based on the uniform layered model Crust 2.0 (Bassin et al., 2000).

source inversion for the event (Ji et al., unpublished manuscript) and strikes a balance between the dip of $48^{\circ}$ associated with the first-motion focal mechanism and the dips of $10^{\circ}$ and $25^{\circ}$ measured at the surface (Eberhart-Phillips et al., 2003). Although to the west of the surface rupture we extend the Denali fault with a uniform strike, it does not actively participate in the rupture process as described later. Figure 1c shows the fault surfaces in unexploded and exploded views, and Table 2 gives the precise orientation and maximum along-strike and down-dip extents of the fault planes.

The normal pressure on the fault surfaces increases with depth due to the lithostatic pressure, assuming hydrostatic pore pressures. This overburden pressure along with the regional tectonic stress prevents fault opening. Along the edge where the Denali and Susitna Glacier faults intersect, the dislocations create right-lateral slip consistent with the Denali fault; in other words, we assume that the Susitna Glacier fault ends just before it reaches the Denali fault. At other locations where the fault planes intersect (e.g., the edges that divide the fault segments), we use the average orientation of the two intersecting planes. Along these edges, small voids and interpenetration do occur because we assume small, elastic strains. However, the voids and interpenetrations are very small compared with the element size.

The rupture model uses a simple slip- and rate-weakening friction model (Fig. 3) that generates pulse-like ruptures (Heaton, 1990; Madariaga and Cochard, 1994). Because many physical processes may influence the shear stress during sliding (e.g., Aagaard et al. [2001] discusses several proposed mechanisms), we choose a nominal sliding shear stress that increases with depth (Fig. 2) and roughly corresponds to a coefficient of friction of 0.1 . In this formulation of the slip- and rate-weakening friction model, we assume that the physical processes controlling the changes in stress on the fault during sliding yield a friction stress that is independent of the normal stress. Although traditional friction model formulations in dynamic rupture simulations use a coefficient of friction to allow dynamic variations in normal stresses to influence the friction stress, they do not include normal stresses that increase with depth corresponding to the overburden pressures. Because the overburden pressures at seismogenic depths are about two orders of magnitude greater than the dynamic changes in normal stresses on the fault, it is plausible to assume that the dynamic changes in normal stresses do not affect the frictional sliding stresses. The formulation used here also provides a simple way to match heat-flow constraints and create distributions of slip that do not have a strong depth dependence in a model with lithostatic normal stresses and hydrostatic pore pressures. Assuming the thickness of the sliding zone varies from $2 \mathrm{~mm}$ at the surface to $3 \mathrm{~cm}$ at $15 \mathrm{~km}$ depth, this level of sliding stress falls near the maximum level that would not imply substantial melting on the fault surface for $3 \mathrm{~m}$ of slip. (See Aagaard et al. [2001] and references therein for a more detailed discussion.)

To isolate the effect of fault geometry and stress orientation from other possible effects such as lateral heterogeneity in the stress field, we assume that the faults are uniformly critically loaded except in the regions with artificially 
Table 2

Fault Geometry

\begin{tabular}{lcccccc}
\hline Fault & Origin & End Point & Strike & Dip & $\begin{array}{c}\text { Length } \\
(\mathrm{km})\end{array}$ & $\begin{array}{c}\text { Width } \\
(\mathrm{km})\end{array}$ \\
\hline DF W & $146.9718^{\circ} \mathrm{W}, 63.5294^{\circ} \mathrm{N}$ & $148.2067^{\circ} \mathrm{W}, 63.5346^{\circ} \mathrm{N}$ & $271.07^{\circ}$ & $80^{\circ}$ & 61.410 & 25.000 \\
DF C & $146.3691^{\circ} \mathrm{W}, 63.4871^{\circ} \mathrm{N}$ & $146.9718^{\circ} \mathrm{W}, 63.5294^{\circ} \mathrm{N}$ & $278.64^{\circ}$ & $80^{\circ}$ & 30.563 & 25.000 \\
DF E & $145.9976^{\circ} \mathrm{W}, 63.4437^{\circ} \mathrm{N}$ & $146.3691^{\circ} \mathrm{W}, 63.4871^{\circ} \mathrm{N}$ & $283.91^{\circ}$ & $80^{\circ}$ & 19.136 & 25.000 \\
SGF W & $147.3511^{\circ} \mathrm{W}, 63.4087^{\circ} \mathrm{N}$ & $147.7034^{\circ} \mathrm{W}, 63.4074^{\circ} \mathrm{N}$ & $270.00^{\circ}$ & $35^{\circ}$ & 17.600 & 19.617 \\
SGF E & $146.9353^{\circ} \mathrm{W}, 63.5269^{\circ} \mathrm{N}$ & $147.3511^{\circ} \mathrm{W}, 63.4087^{\circ} \mathrm{N}$ & $237.00^{\circ}$ & $35^{\circ}$ & 24.555 & 19.814 \\
\hline
\end{tabular}

Parameters defining fault geometry on the Denali fault (DF) and Susitna Glacier fault (SGF) segments with segments designated as west (W), central (C), or east (E). The fault surfaces are trimmed polygons created from the planes defined by the surface traces and dip angle (see Fig. 1).

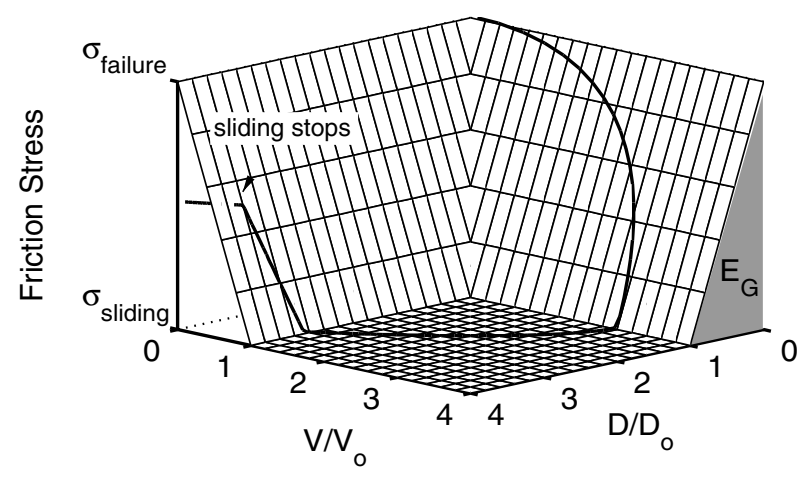

Figure 3. Slip- and rate-weakening friction model. The surface defines the friction stress as a function of slip $(D)$ normalized by the slip-weakening parameter $\left(D_{0}\right)$ and slip rate $(V)$ normalized by the slip-rate threshold $\left(V_{0}\right)$. The shading region corresponds to the fracture energy. The thick line illustrates a typical trajectory of the friction stress, which decreases as slip increases, drops to a nominal sliding level, and then increases when the slip rate drops below the threshold. During restrengthening, when the friction rises to a high enough level to oppose the loading, sliding stops and the stress level drops below the failure envelope defined by the friction model.

reduced initial shear stress (western ends of the Susitna Glacier and Denali faults). This means that the ratio of the strain energy released to the fracture energy is sufficiently high that ruptures propagate to the full lateral extents of the fault planes. Following Day (1982) and Madariaga and Olsen (2000) this can be expressed quantitatively by

$$
\kappa=\frac{\left(\sigma_{0}-\sigma_{\text {sliding }}\right)^{2} L}{E_{G} \mu}=0.44
$$

over the regions of unstable sliding where we have set the length scale, $L$, to $1 \mathrm{~km}$ and the other quantities are given later in equations (2) to (5). Hence, if the rupture on the Susitna Glacier fault is able to nucleate a rupture on the Denali fault, then it will continue and ultimately propagate to the eastern extent of the fault present in the model.

Because of the great uncertainty in the stress field, for simplicity we assume that the various fault planes all have the same level of shear stress and frictional properties. We set the friction-model parameters to create unstable sliding (initial shear stress is greater than the sliding stress) over depths of $0.5-16 \mathrm{~km}$ as shown in Figure $2 \mathrm{~b}$, with stable sliding above this region to mimic inelastic deformation in the soft, near-surface material and below this region to allow graceful termination of the rupture at depth. The dynamic stress drop divided by the shear modulus is uniform with depth, with the magnitude selected by trial and error to yield the appropriate amount of slip. These variations in the initial stress $\left(\sigma_{0}\right)$, sliding stress $\left(\sigma_{\text {sliding }}\right)$, failure stress $\left(\sigma_{\text {fail }}\right)$, and fracture energy $\left(E_{G}\right)$ are summarized by

$$
V_{0}=0.2 \mathrm{~m} / \mathrm{sec}
$$

$$
\sigma_{0}=1.6667 \times 10^{6} \frac{\mathrm{MPa}}{\mathrm{km}} z+2.8909 \times 10^{-4} \mu,
$$

$$
\left.\begin{array}{rl}
\sigma_{\text {sliding }} & =-1.6667 \times 10^{6} \frac{\mathrm{MPa}}{\mathrm{km}} z \\
E_{G} / \mu & =1.8791 \times 10^{-4} \\
S & =\frac{\sigma_{\text {fail }}-\sigma_{0}}{\sigma_{0}-\sigma_{\text {sliding }}}=0.876
\end{array}\right\} \begin{aligned}
& -15 \mathrm{~km} \leq z \leq \\
& -1.0 \mathrm{~km}, \quad \text { and }
\end{aligned}
$$

$$
\left.\begin{array}{rl}
\sigma_{\text {sliding }}= & -1.6667 \times 10^{6} \frac{\mathrm{MPa}}{\mathrm{km}} z \\
& +5.4238 \times 10^{-4} \mu \\
E_{G}= & 0 \\
\sigma_{\text {fail }}= & 0
\end{array}\right\} \begin{aligned}
& z=0 \mathrm{~km} \text { or } \\
& z \leq-15 \mathrm{~km},
\end{aligned}
$$

where $z$ is positive upward, $\mu$ is the shear modulus, and $V_{0}$ is the slip rate at which restrengthening begins (see Fig. 3). For locations between these two regions, we linearly interpolate to create the transitions shown in Figure 2. The slipweakening parameter, $D_{0}$, is defined by the failure stress, the sliding stress, and the fracture energy. Thus, it is used to 
stabilize the numerical solution and does not correspond to any physical property of the material.

The failure stress relative to the initial stress and dynamic stress drop is often given in terms of a nondimensional parameter called the strength excess, $S=\left(\sigma_{\text {fail }}-\sigma_{0}\right) /$ $\left(\sigma_{0}-\sigma_{\text {sliding }}\right)$ (Andrews, 1976; Das and Aki, 1977). In our discrete model, the level of shear stress at the leading edge of the rupture is a function of the spatial resolution of the model, which is closely correlated with the wavelength of the radiated seismic waves. Consequently, the strength excess for a given fracture energy is a parameter that depends on the spatial resolution of the model (Guatteri and Spudich, 2000), so that the failure stress in the Earth is much larger than the one used here, which is associated with a spatial resolution suited for waves with periods of $2 \mathrm{sec}$ and longer. For example, increasing the spatial resolution by a factor of 2 (suitable for propagation of waves with periods down to $1.0 \mathrm{sec}$ ) would allow a significantly larger strength excess and a correspondingly smaller slip-weakening parameter for the same fracture energy.

We force the appropriate western termination of the rupture by reducing the shear stress along the western portions of the fault surfaces. This allows smooth termination of the rupture on the westernmost portion of the Susitna Glacier fault and prevents slip a priori on the portion of the Denali fault west of the surface rupture. This is conceivably realistic if, for example, the 1912 event broke this section of the Denali fault (Doser, 2004).

Having established the magnitude of the initial shear stress through the friction model parameters with critically loaded faults, the orientation of the shear stress comes from resolving the regional stress field onto the fault planes. Thus, the stresses on the fault surfaces at the beginning of the simulations are the sum of the overburden pressures, the nominal sliding shear stresses applied in the direction of the regional stress field, and the regional stress tensor resolved onto each fault plane, scaled such that the magnitude of the shear stress matches the depth dependence given in equations (2) to (5). This corresponds to loading from a regional stress field superimposed on a background stress field comprising the overburden pressures and nominal shear stresses that increase with depth.

We consider several possible orientations for the regional stress field in the hypocentral region (region R1 in Ratchkovski [2003]) based on the orientation computed from focal mechanisms of events prior to the Denali fault sequence. This regional stress orientation results in rake angles associated with the shear stress of about $160^{\circ}$ on the Denali fault and $170^{\circ}$ on the western portion of the Susitna Glacier fault (see Table 3). Such shear-stress orientations produce too much dip-slip motion on the Denali fault and too much lateral motion on the Susitna Glacier fault (as discussed later). Consequently, we also consider perturbations from this orientation consisting of increases in the difference between the maximum horizontal compressive stress and the vertical stress (moving the stress orientation away from al- most pure strike-slip faulting toward a mixture of strike-slip and reverse faulting) and rotations of the stress tensor. We refer to these scenarios as Ra-Rd. We also consider scenario Aa, which appears to produce slip directions closer to the ones measured in the Denali fault earthquake but has a stress orientation that differs from the regional stress orientation of region R1 in Ratchkovski (2003) by about $20^{\circ}$.

\section{Results}

We initiate the rupture on the Susitna Glacier fault at the mainshock epicenter (Alaska Earthquake Information Center [AEIC]: $147.4440^{\circ} \mathrm{W}, 63.5175^{\circ} \mathrm{N}$ ) at a depth of $8.5 \mathrm{~km}$. This requires moving the AEIC hypocenter $4.6 \mathrm{~km}$ deeper to be consistent with our fault geometry. We force the onset of rupture by using a circular region with a radius of $2.5 \mathrm{~km}$ in which the shear stress is $2 \%$ above the failure stress. The rupture propagates outward, with surface rupture progressing toward the east.

In all five scenarios ( $\mathrm{Ra}-\mathrm{Rd}$ and $\mathrm{Aa}$ ) as slip occurs on the Susitna Glacier fault, it increases the shear stress on the Denali fault on the footwall side of the intersection between the two faults while decreasing the shear stress on the hanging-wall side. Figure 4 displays snapshots of the slip rate and change in shear stress for scenario Rd. The small length scale heterogeneities in the shear stresses arise from the rate dependence in the friction model and are associated with poor numerical resolution of the healing front as opposed to inadequate resolution of the leading edge of the rupture identified by Rice (1993). Formulating friction models with adequate resolution of both the leading and trailing (healing) edges of the rupture is an area of ongoing work.

The continuing development of slip near the intersection triggers slip on the Denali fault $9.5 \mathrm{sec}$ after nucleation. This is in agreement with kinematic source inversions that show coherent slip beginning on the Denali fault $10 \mathrm{sec}$ (Ji et al., unpublished manuscript) or $12 \mathrm{sec}$ (Dreger et al., 2004) after initiation on the Susitna Glacier fault. We favor triggering at $10 \mathrm{sec}$ because Ji et al. (unpublished manuscript) do a better job of matching the geometry of the Susitna Glacier fault. In scenario Rc, the limited amount of right-lateral motion on the Susitna Glacier fault fails to increase the shear stress over a large enough area to sustain rupture on the Denali fault and the rupture ends. Reducing the failure stress would allow triggering but would result in a faster rupture speed, which would produce earlier rupture of the Denali fault and create a significant misfit in the timing of the triggering. In the other four cases, the rupture on the Denali fault continues toward the east and propagates down the fault. On the hanging-wall side of the Susitna Glacier fault, slip does not occur on the Denali fault due to the stress shadow from slip on the Susitna Glacier fault; on the footwall side, the rupture propagates only a few kilometers toward the west before hitting the imposed lower level of shear stress that extinguishes the rupture. Later, we discuss the stress changes near the intersection in more detail through 
Table 3

Scenario Stress Orientations

\begin{tabular}{|c|c|c|c|c|c|c|c|c|c|}
\hline \multirow[b]{2}{*}{ Scenario } & \multicolumn{3}{|c|}{ Principal Stress Directions } & \multirow{2}{*}{$R=\frac{\sigma_{\mathrm{H}}-\sigma_{\mathrm{v}}}{\sigma_{\mathrm{H}}-\sigma_{\mathrm{h}}}$} & \multicolumn{5}{|c|}{ Shear-Stress Rake Angle } \\
\hline & $\sigma_{H}$ & $\sigma_{v}$ & $\sigma_{h}$ & & DF W & DF C & DF E & SGF W & SGF E \\
\hline $\mathrm{Ra}^{*}$ & $13^{\circ} \mathrm{N}, 37^{\circ} \mathrm{W}$ & $71^{\circ} \mathrm{N}, 94^{\circ} \mathrm{E}$ & $14^{\circ} \mathrm{N}, 130^{\circ} \mathrm{W}$ & 0.6 & $158^{\circ}$ & $161^{\circ}$ & $162^{\circ}$ & $172^{\circ}$ & $119^{\circ}$ \\
\hline $\mathrm{Rb}^{\dagger}$ & $13^{\circ} \mathrm{N}, 37^{\circ} \mathrm{W}$ & $71^{\circ} \mathrm{N}, 94^{\circ} \mathrm{E}$ & $14^{\circ} \mathrm{N}, 230^{\circ} \mathrm{W}$ & 0.8 & $153^{\circ}$ & $158^{\circ}$ & $159^{\circ}$ & $150^{\circ}$ & $104^{\circ}$ \\
\hline $\mathrm{Rc}^{\ddagger}$ & $0^{\circ} \mathrm{N}, 37^{\circ} \mathrm{W}$ & $76^{\circ} \mathrm{N}, 52^{\circ} \mathrm{E}$ & $14^{\circ} \mathrm{N}, 127^{\circ} \mathrm{W}$ & 0.8 & $168^{\circ}$ & $171^{\circ}$ & $172^{\circ}$ & $146^{\circ}$ & $102^{\circ}$ \\
\hline $\mathrm{Rd}^{\S}$ & $7^{\circ} \mathrm{N}, 41^{\circ} \mathrm{W}$ & $80^{\circ} \mathrm{N}, 92^{\circ} \mathrm{E}$ & $7^{\circ} \mathrm{N}, 132^{\circ} \mathrm{W}$ & 0.8 & $164^{\circ}$ & $168^{\circ}$ & $169^{\circ}$ & $151^{\circ}$ & $106^{\circ}$ \\
\hline $\mathrm{Aa}^{\#}$ & $0^{\circ} \mathrm{N}, 45^{\circ} \mathrm{W}$ & $90^{\circ} \mathrm{N}, \quad 0^{\circ} \mathrm{E}$ & $0^{\circ} \mathrm{N}, 135^{\circ} \mathrm{W}$ & 0.9 & $172^{\circ}$ & $175^{\circ}$ & $176^{\circ}$ & $147^{\circ}$ & $106^{\circ}$ \\
\hline
\end{tabular}

$\sigma_{H}, \sigma_{v}$, and $\sigma_{h}$ correspond to the maximum horizontal compressive stress, the vertical stress, and the minimum horizontal compressive stress, respectively. Principal stress directions are given by plunge and azimuth. $R$ denotes the tectonic regime with $R=0.5$ corresponding to strike-slip faulting and $R=1.0$ corresponding to a mixture of reverse and strike-slip faulting.

*Stress orientations from Ratchkovski (2003).

"Increase $R$ from 0.6 to 0.8 , consistent with a mixture of strike-slip and reverse faulting.

*Reduce plunge of maximum compressive stress direction to generate less dip-slip on the DF.

${ }^{\S}$ Rotate principal stress tensor $10^{\circ}$ about $18.1^{\circ} \mathrm{N} 1.45^{\circ} \mathrm{E}$, this is half-way between the orientation in scenarios $\mathrm{Rb}$ and $\mathrm{Aa}$.

${ }^{\#}$ Orientation with better fit to sense of motion in a kinematic source inversion and measured at the ground surface.

examination of time histories and trajectories of the shear stress for a pair of locations on the Denali fault that span its intersection with the Susitna Glacier fault.

Figure 5 shows the advancement of the rupture for scenario Rd in more detail by showing the time when slip begins for each point on the fault surfaces. The rupture propagates at about $80 \%$ of the shear-wave speed on the Susitna Glacier fault and reaches the surface after $5.5 \mathrm{sec}$. The rupture continues propagating toward the intersection of the two faults, and the rupture jumps to the Denali fault at a depth of $3 \mathrm{~km}$ $9.5 \mathrm{sec}$ after nucleation. The rupture advances down-dip and along-strike on the Denali fault with along-strike propagation driven by slip near the surface. With the shear-wave speed increasing with depth, the rupture propagates faster at depth (even though the rupture speed relative to the shearwave speed remains at about $80 \%$ of the shear-wave speed) and eventually surpasses the shallow portion, so that beginning at around $25 \mathrm{sec}$, slip at depth drives the propagation of the rupture at the surface. The propagation of the other four ruptures that jump onto the Denali fault is similar.

As mentioned previously, the ruptures in scenarios Ra, $\mathrm{Rb}, \mathrm{Rd}$, and Aa (all but scenario Rc) all jump from the Susitna Glacier fault to the Denali fault. As seen from Figure 6, the distributions of final slip for these four scenarios are very similar. However, the different stress orientations produce different slip directions on the fault surfaces. The direction of slip closely follows the direction of applied shear stress with only small differences between the direction of the initially applied shear stress and the average rake angle of the final slip (comparing Tables 3 and 4).

These differences between the direction of the initial shear stress and the direction of slip arise from the dynamic shear-stress changes not being aligned with the initial shear stresses. Figure 7 shows the shear-stress time histories and their trajectories in the fault plane for a pair of locations on the Denali fault $2 \mathrm{~km}$ above and below its intersection with the Susitna Glacier fault. The shallow location is at a depth of $1.915 \mathrm{~km}$ at $147.1084^{\circ} \mathrm{W}, 63.5336^{\circ} \mathrm{N}$, and the deep location is at a depth of $5.836 \mathrm{~km}$ at $147.1130^{\circ} \mathrm{W}, 63.5398^{\circ} \mathrm{N}$. As slip occurs on the Susitna Glacier fault in the first $10 \mathrm{sec}$ of the rupture, the shear stress increases at the location below the intersection and decreases at the location above the intersection. The location above the intersection sits on the hanging-wall side of the Susitna Glacier fault and does not experience slip in any of the scenarios, whereas the location below the intersection sits on the footwall side of the Susitna Glacier fault and experiences slip in all scenarios except Rc. At the location on the footwall side of the Susitna Glacier fault, the final shear stress is significantly below the initial stress in scenarios $\mathrm{Rb}, \mathrm{Rd}$, and Aa. As expected, the final shear stress is higher than the initial shear stress in scenario Rc where the Susitna Glacier fault rupture loads the Denali fault but slip does not occur. In scenario Ra the final shear stress is higher than the initial shear stress despite the fact that slip occurs; this is due to the combination of its proximity to the western termination of the rupture where energy is absorbed and the rate dependence in the friction model which allows rapid restrengthening as the slip rate drops below $0.10 \mathrm{~m} / \mathrm{sec}$.

At the location on the hanging-wall side of the Susitna Glacier fault in scenarios $\mathrm{Ra}$ and $\mathrm{Rb}$, the changes in shear stress almost exactly oppose the initial shear stress, so that the trajectory heads toward the origin (zero shear stress). In scenarios Rc, Rd, and Aa, the trajectories display a more complex pattern, at first moving roughly tangential to the direction of initial shear stress before heading toward the origin as in the other two scenarios. At the location on the footwall side of the Susitna Glacier fault, the shear stress trajectories all display a similar pattern, the shear-stress changes are in a direction slightly up-dip from the direction 

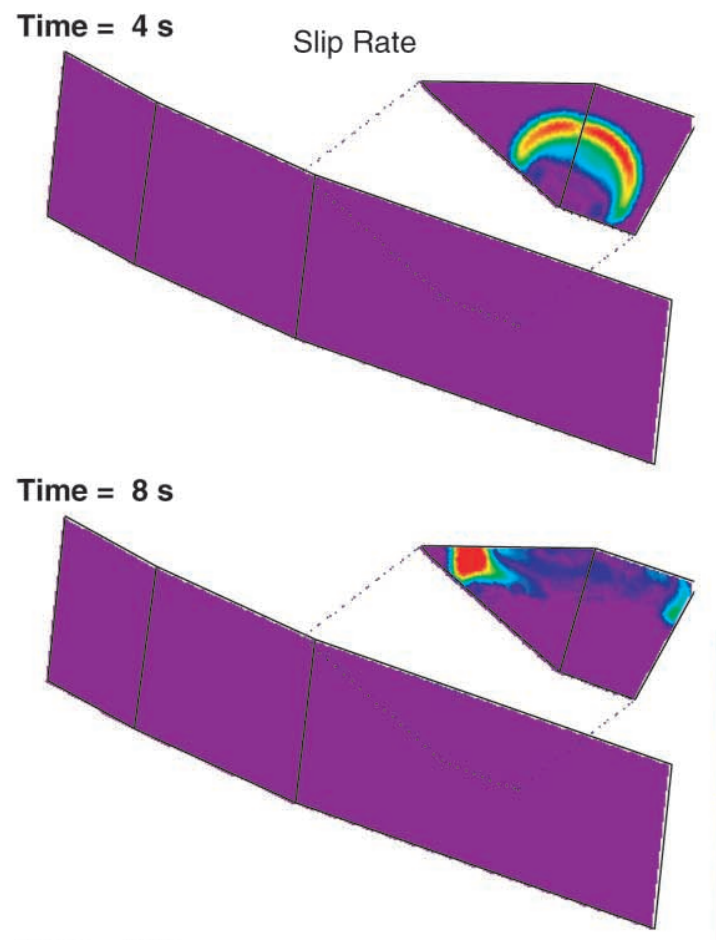

Time $=12 \mathrm{~s}$

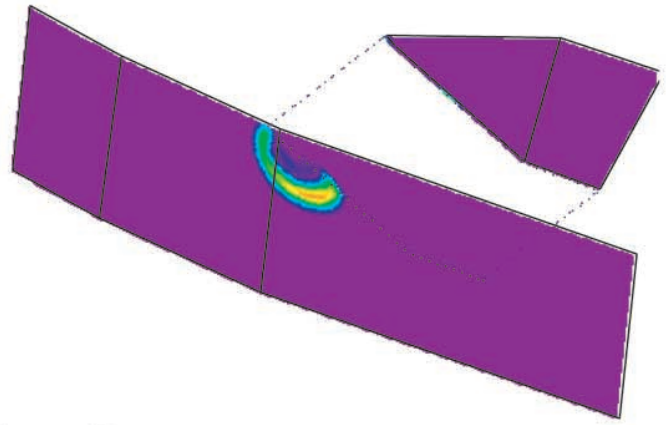

Time $=16 \mathrm{~s}$

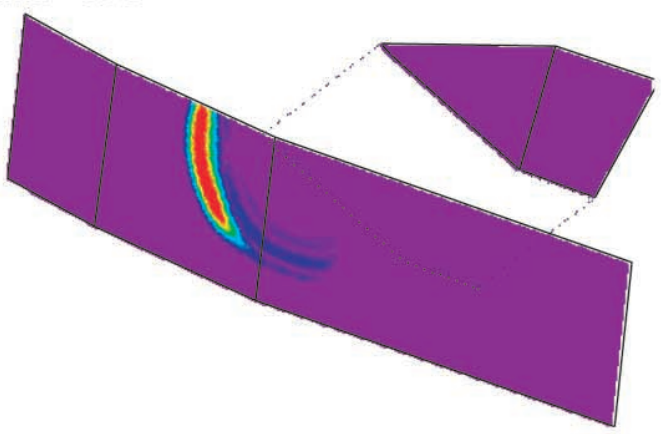

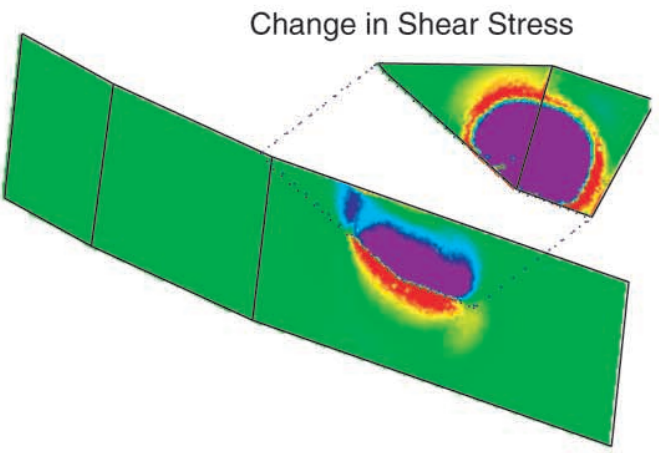
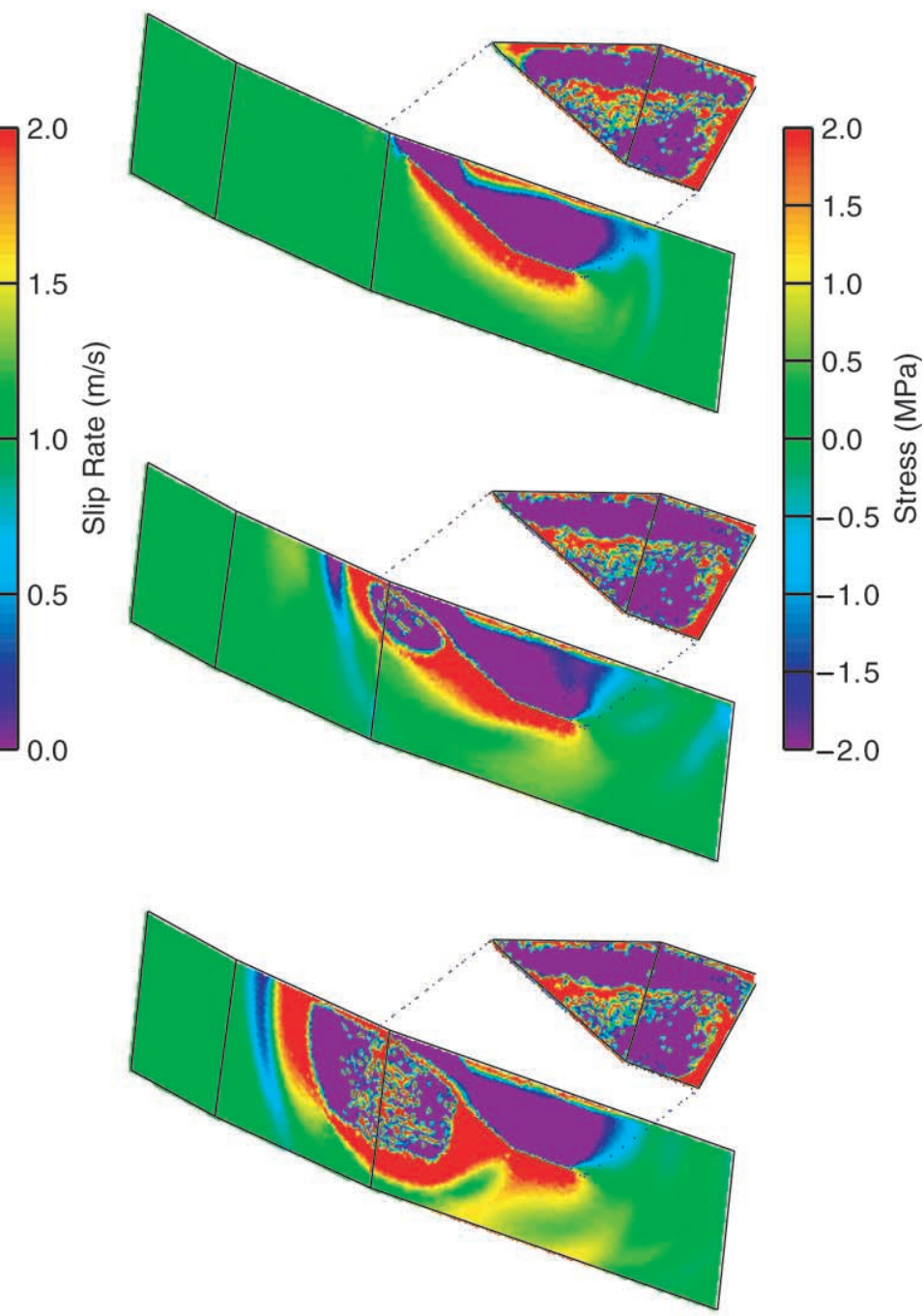

Figure 4. Snapshots of slip rate (left) and change in shear stress (right) on the (exploded) fault surfaces for scenario Rd as viewed from the northwest. Slip on the Susitna Glacier fault loads the Denali fault on the footwall side of the Susitna Glacier fault and unloads it on the hanging-wall side. Rupture jumps to the Denali fault at $9.5 \mathrm{sec}$. 


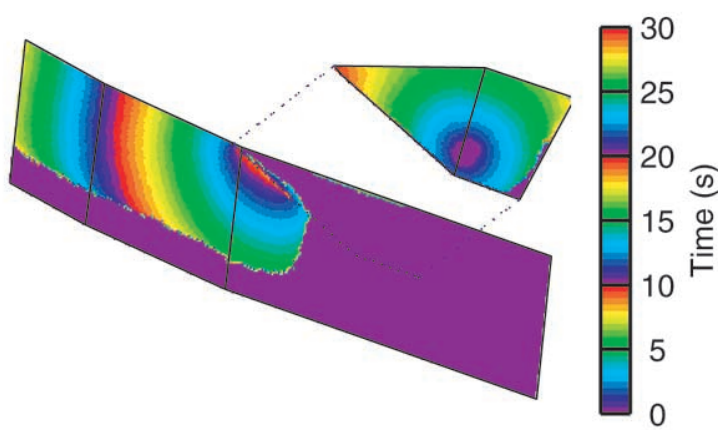

Figure 5. Time at which slip begins $(D>1 \mathrm{~cm})$ at each point on the (exploded) fault surfaces for scenario Rd as viewed from the northwest. Locations that do not slip have times set to zero. The transition of rupture from the Susitna Glacier fault to the Denali fault occurs at $9.5 \mathrm{sec}$.

of the initial shear stress, with the smallest deviation in scenario $\mathrm{Rb}$ and the largest in scenario Rc. This large deviation is the principal reason why, in scenario Rc, the shear stress does not reach the failure stress and slip does not occur. Thus, the shear-stress trajectories show that slip on the Susitna Glacier fault causes shear-stress changes on the Denali fault in directions similar to that of the shear stress from the regional stress field, with increases below the Susitna Glacier fault (footwall side) and decreases above the Susitna Glacier fault (hanging-wall side). This means that reducing the initial, failure, and sliding shear stresses by a constant value, consistent with a lower level of shear stress and weaker faults, would yield similar results, so that the dynamic triggering of rupture on the Denali fault from rupture of the Susitna Glacier fault is relatively independent of the overall level of shear stress and fault strength.

\section{Discussion}

For the four scenarios that appear to replicate the rupture jumping from the Susitna Glacier fault to the Denali fault about $10 \mathrm{sec}$ after nucleation, we consider how well each one reproduces the general features of the rupture. Through selection of the friction-model parameters, the scenarios produce the correct amount of slip: about $3 \mathrm{~m}$ of slip on the Susitna Glacier fault and 1-2 $\mathrm{m}$ of slip in the early portion of the Denali fault rupture (Eberhart-Phillips et al., 2003; Dreger et al., 2004; Ji et al., unpublished manuscript). The match in the timing of the rupture transition indicates we also match the average rupture speed on the Susitna Glacier fault. As expected from the shear-stress orientations, scenarios $\mathrm{Ra}$ and $\mathrm{Rb}$ produce much more dip-slip on the Denali fault than what was measured at the surface (EberhartPhillips et al., 2003) or inferred at depth (Ji et al., unpublished manuscript). In addition, although poorly constrained by the data, the western portion of the Susitna Glacier fault has too little dip-slip motion. The average rake angle of $170^{\circ}$ on this thrust fault corresponds to considerably less dip-slip

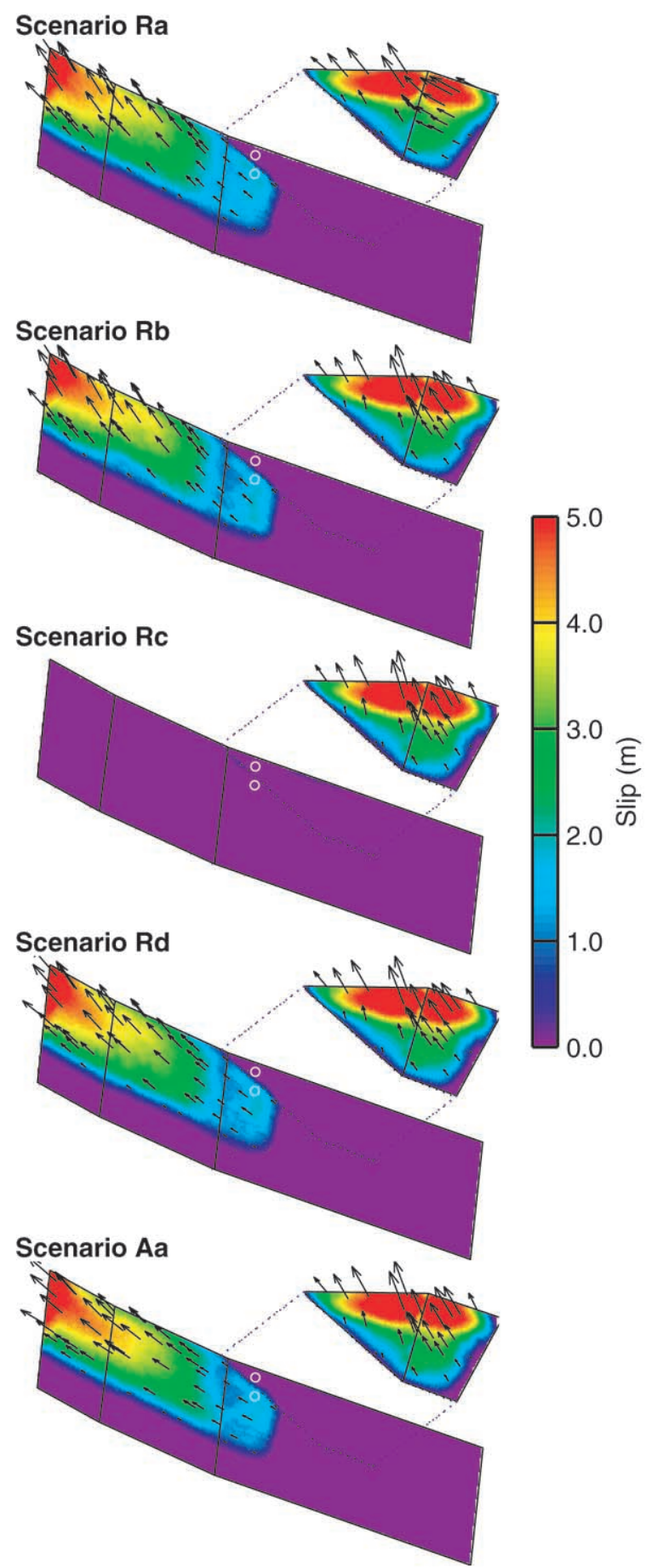

Figure 6. Final slip on the (exploded) fault surfaces for each of the five scenarios as viewed from the northwest. The shading denotes the magnitude of the final slip, and the arrows denote both the magnitude and direction. Figure 7 displays the shear-stress time histories at the locations identified by the circles. Scenarios $\mathrm{Ra}$ and $\mathrm{Rb}$ have too much dip slip on the DF and scenario Ra has too much lateral slip on the western (right) portion of the SGF. Rupture does not propagate onto the DF in scenario Rc. Scenarios Rd and Aa agree more closely with inferred slip directions. 
Table 4

Summary of Earthquake Rupture Slip

\begin{tabular}{|c|c|c|c|c|c|c|c|c|c|c|c|c|c|c|c|}
\hline \multirow[b]{3}{*}{ Scenario } & \multicolumn{15}{|c|}{ Fault Segment } \\
\hline & \multicolumn{3}{|c|}{ DF W } & \multicolumn{3}{|c|}{$\mathrm{DF} C$} & \multicolumn{3}{|c|}{ DF E } & \multicolumn{3}{|c|}{ SGF W } & \multicolumn{3}{|c|}{ SGF E } \\
\hline & $M_{\mathrm{w}}$ & $\bar{D}$ & $\lambda$ & $M_{\mathrm{w}}$ & $\bar{D}$ & $\lambda$ & $M_{\mathrm{w}}$ & $\bar{D}$ & $\lambda$ & $M_{\mathrm{w}}$ & $\bar{D}$ & $\lambda$ & $M_{\mathrm{w}}$ & $\bar{D}$ & $\lambda$ \\
\hline $\mathrm{Ra}$ & 6.6 & 1.1 & 158 & 7.1 & 2.2 & 154 & 7.0 & 3.3 & 153 & 6.9 & 2.8 & 170 & 6.9 & 3.2 & 124 \\
\hline $\mathrm{Rb}$ & 6.6 & 1.1 & 154 & 7.0 & 2.2 & 150 & 7.0 & 3.2 & 150 & 6.9 & 2.8 & 148 & 6.9 & 3.3 & 110 \\
\hline $\mathrm{Rc}$ & 5.2 & 0.1 & 176 & 4.1 & 0.0 & 163 & - & 0.0 & - & 6.9 & 2.7 & 144 & 6.9 & 3.3 & 107 \\
\hline $\mathrm{Rd}$ & 6.6 & 1.0 & 163 & 7.1 & 2.2 & 161 & 7.0 & 3.4 & 161 & 6.9 & 2.8 & 149 & 6.9 & 3.4 & 111 \\
\hline $\mathrm{Aa}$ & 6.6 & 1.0 & 170 & 7.1 & 2.4 & 170 & 7.0 & 3.4 & 170 & 6.9 & 2.8 & 145 & 6.9 & 3.4 & 111 \\
\hline
\end{tabular}

Moment magnitude, average slip $(\bar{D})$ in meters, and average slip-rake angle $(\lambda)$ in degrees on each fault segment for all five scenarios. The slip direction closely follows the direction of resolved shear stress with small perturbations due to the breakout of the rupture at the ground surface on the SGF and the dynamic loading of the DF by the SGF rupture.

motion than the amount that occurs on the Denali fault, a fault with predominantly lateral motion. Thus, scenario Ra appears inconsistent with the data. The stress orientation in scenario $\mathrm{Ra}$ would generally continue to produce a poor match even with variations to the fault geometry on the western portion of the Susitna Glacier fault. The surface trace clearly shows a strike in the east-west direction, so that any north-dipping plane that conforms to the surface rupture will have too little shear stress in the dip-slip direction with this stress orientation.

The stress orientations consistent with a mixture of strike-slip and reverse faulting (scenarios $\mathrm{Rb}, \mathrm{Rc}, \mathrm{Rd}$, and Aa) appear to generate slip directions on the Susitna Glacier fault more consistent with the data by having much less right-lateral motion. In addition the amount of dip-slip motion on the Denali fault decreases, bringing the rake angles closer to the near-horizontal orientations that were measured. Rotating the regional stress tensor so that the maximum compressive stress direction shifts toward the west with a more horizontal orientation (scenarios $\mathrm{Rd}$ and $\mathrm{Aa}$ ) further reduces the amount of dip-slip motion on the Denali fault. As a result, scenarios $\mathrm{Rd}$ and $\mathrm{Aa}$, with slightly rightlateral oblique motion on the Susitna Glacier fault and rightlateral motion on the Denali fault (with a little north side up dip-slip motion) provide the closest fit to the observed slip orientations. Both of these stress orientations are consistent with the very few focal mechanisms available for the region with misfits of about $10^{\circ}$ in the predicted rake angles for the east-west striking right-lateral nodal planes (Jeanne Hardebeck, personal comm., 2004). Thus, scenario Aa, which does a slightly better job of matching the inferred rake angles than scenario Rd, is our preferred model.

One feature not reproduced by the four scenarios is the approximately $5 \mathrm{~km}$ of surface rupture on the Denali fault that was observed to the west of its intersection with the Susitna Glacier fault (Eberhart-Phillips et al., 2003). In our models, slip only occurs on the footwall side of the Susitna Glacier fault, that is, slip on the Denali fault occurs only at depth to the west of the intersection. This discrepancy likely results from not including lateral heterogeneity in the stress field (which is unknown) and the poorly constrained geometry of the Susitna Glacier fault, particularly its orientation at depth near the Denali fault. An elevated initial shear stress on the Denali fault west of the intersection could allow some surface rupture to occur even though this region falls into a stress shadow for much of the rupture. More likely, the geometry of the faults in conjunction with heterogeneity in the stress field caused this feature. Oglesby et al. (2003b) demonstrated these two factors may have controlled the rupture under somewhat similar circumstances at the northern end of the rupture in the 1999 Hector Mine earthquake. Thus, the fault geometry and background stress orientation appear to explain why this rupture of the Susitna Glacier fault triggered the rupture to the east on the Denali fault.

In these dynamic rupture models, dynamic shear stress increases on the order of the dynamic stress drop are enough to raise the shear stress above the failure threshold. Such a low failure stress is required by the relatively coarse spatial resolution of the model (wavelengths corresponding to waves with periods of $2 \mathrm{sec}$ and longer). A finer spatial resolution produces larger dynamic shear-stress changes and permits a larger failure stress for a given fracture energy (Guatteri and Spudich, 2000; Aagaard et al., 2001). Therefore, the dynamic shear-stress changes in this model required for a rupture to trigger slip on surrounding faults are a resolutiondependent parameter and are much smaller than the stress changes that would be necessary to trigger slip in a real earthquake. Nevertheless, the models do a good job of explaining the features of the rupture jumping from the Susitna Glacier fault to the Denali fault at this length scale.

Understanding when ruptures may jump across stepovers and/or immediately trigger other ruptures on nearby faults is an important issue for accurately estimating the seismic hazard. With the stress orientation and fault geometry playing such important roles, it appears that, in many cases, location-specific investigations will be needed to determine if a particular fault could potentially trigger rupture on neighboring faults. Other local and event-specific features, such as stress and strength heterogeneity, will also be im- 
Shear Stress Magnitude vs. Time Shear Stress Traj., SGF hanging wall

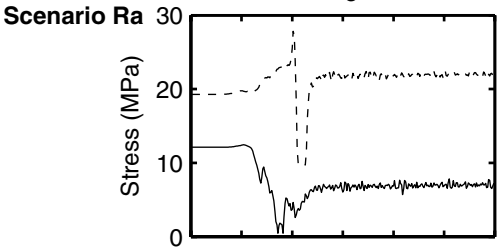

Scenario R

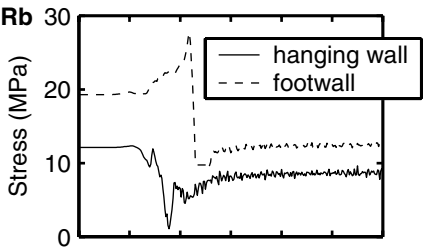

Scenario $\mathrm{Rc}$

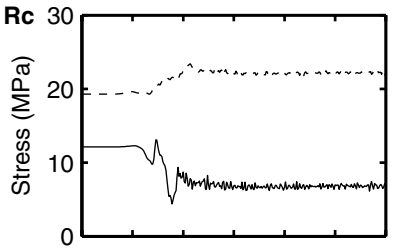

Scenario $\mathrm{Rd}$
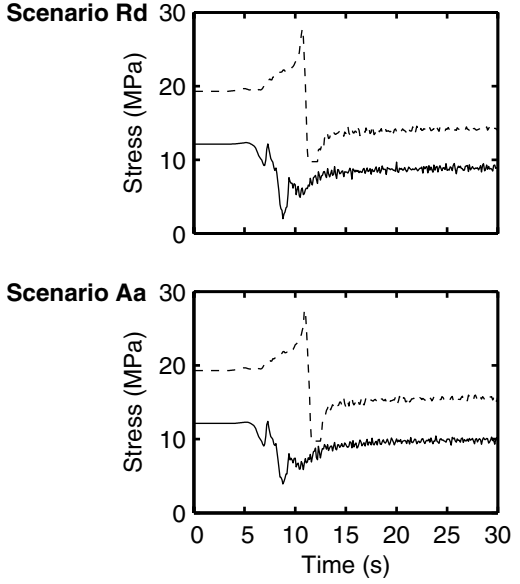
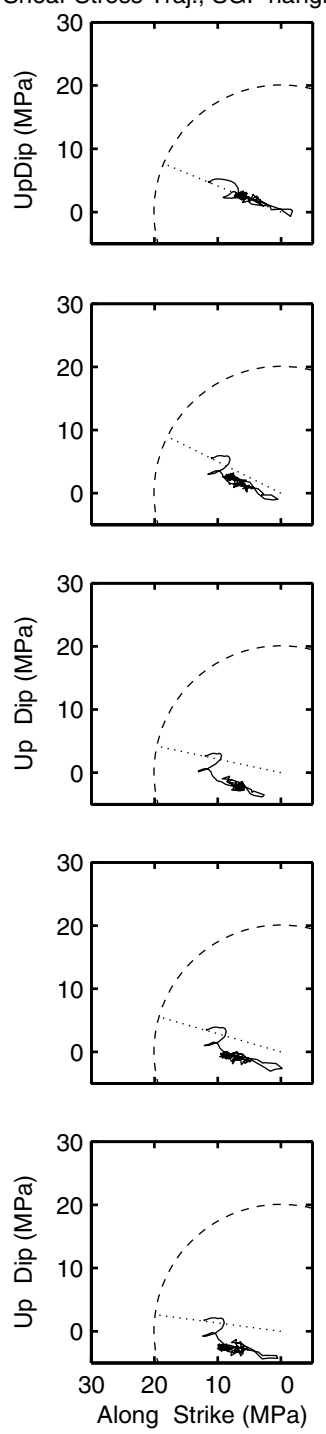
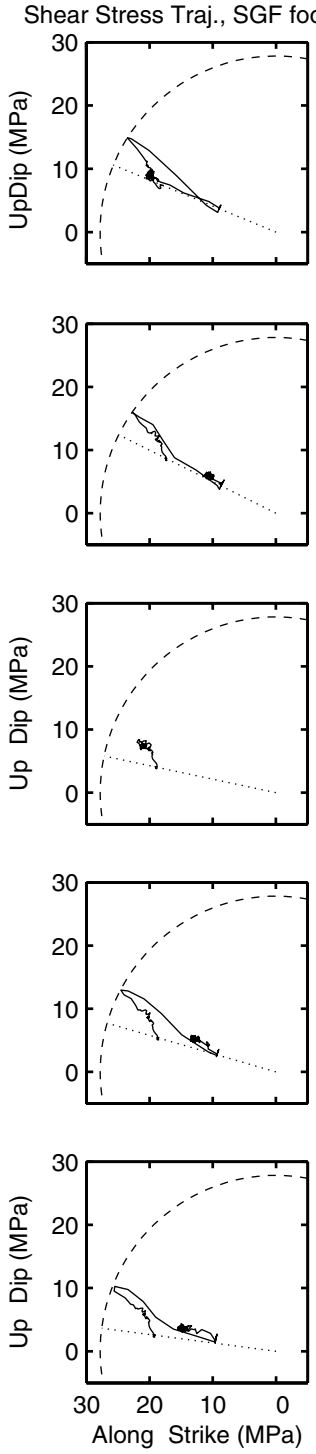

Figure 7. Shear-stress time histories (left) and trajectories (right) for a pair of locations on the Denali fault (circles in Fig. 6). The locations sit $2 \mathrm{~km}$ up-dip and downdip from the intersection of the Susitna Glacier fault surface with the Denali fault surface and about $6 \mathrm{~km}$ west of the intersection of the surface traces. The dashed circles in the shear-stress trajectories delineate the failure envelope, and the dotted lines show the direction of the initial shear stress. The rupture of the Susitna Glacier fault in the first $10 \mathrm{sec}$ increases the shear stress on the footwall side of the Susitna Glacier fault while decreasing the shear stress on the hanging-wall side. The unloading tends to occur along the same direction as the initial shear stress, but the loading tends to occur up-dip from the direction of the initial shear stress.

portant in evaluating whether a rupture will propagate through a junction or jump a gap.

Before an earthquake, we generally have better knowledge of the fault geometry and the regional stress orientation than of the fault friction and stress magnitudes. Of course, in this case the Susitna Glacier fault had not yet been recognized (Eberhart-Phillips et al., 2003) and the regional stress orientation had not been studied. Nevertheless, selecting a minimal parameterization of the rupture dynamics (dynamic stress drop, fracture energy, and failure stress) that yields reasonable values of slip, slip rate, and rupture speed limits the uncertainty in the models. Thus, had we conducted this study a priori with the now known fault geometry and estimate of the regional stress orientation, we would have likely concluded that ruptures on the Susitna Glacier fault might trigger ruptures on the Denali fault. If applied systematically, this approach involving scenario simulations for a given region could provide a more physical basis to probabilistic seismic hazard analyses.

For example, we applied the modeling technique used 
here to examine whether events similar to the 2002 Denali fault earthquake could occur across the San Andreas and San Jacinto strike-slip systems and the Sierra Madre/ Cucamonga thrust fault system (Anderson et al., 2003). Although the friction parameters, normalized by the shear modulus, remain the same, we adjusted the material properties and stress orientation to match the well-constrained data for the region. We found that an analogous event (rupture on the Cucamonga fault triggering rupture of the San Jacinto or San Andreas faults) is highly unlikely, because the Cucamonga fault has slightly left-lateral oblique motion as opposed to the right-lateral oblique motion of the Susitna Glacier fault. However, it is possible for a rupture on the northern portion of the San Jacinto fault to trigger rupture of the Cucamonga and Sierra Madre faults, provided the faults are critically loaded and slip of at least $3 \mathrm{~m}$ occurs on the San Jacinto fault but does not proceed north of the $\mathrm{Cu}$ camonga fault. Such an event, while rarer than a similarly sized $M_{\mathrm{w}} 7.5-7.8$ event on the San Andreas fault, would occur much closer to the densely populated Los Angeles metropolitan area.

The simultaneous strike-slip and thrust rupture in these studies differ, we think, from that of the 1957 Gobi-Altay event. In our models of the 2002 Denali fault earthquake and the possible triggering across the San Jacinto, San Andreas, and Sierra Madre fault systems, the three-dimensional triangular prismatic intersection between a thrust fault and strike-slip fault controls the interaction and rupture transition from the thrust fault to the strike-slip fault, and vice versa. On the other hand, both cases of rupture progression investigated by Kurushin et al. (1997) involved considerably different geometries in which the thrust and strike-slip faults were subparallel. Some insights from our dynamic modeling may apply to the complex and somewhat similar fault junction of the primary Bogd rupture (analogous to the Denali fault) and the combined Toromhon overthrust and Tsagaan Ovoo-Tevsh uul rupture (analogous to the Susitna Glacier fault) in 1957. From our analyses to date, however, it seems necessary to conduct a specific study of the 1957 Gobi-Altay event to assess dynamic triggering in that case, because it almost certainly differed substantially from that in the 2002 Denali fault earthquake.

\section{Conclusions}

Dynamic (spontaneous) rupture simulations for several orientations of the regional stress tensor replicate the transition of rupture from the Susitna Glacier fault to the Denali fault about $10 \mathrm{sec}$ after nucleation. Selection of the proper friction-model parameters results in the ruptures producing distributions and amounts of slip that compare well with the kinematic models and observations. Although using the regional stress orientation derived by others from focal mechanisms results in the transition of rupture at about the correct time, it does not appear to produce the correct orientation of slip on the fault surfaces, as inferred from the measurements of the surface rupture and kinematic source inversions. Improving the fits to the orientation of slip can be accomplished with slight perturbations of the regional stress tensor: adjustment of the intermediate principal stress so that it is more consistent with a mixture of strike-slip and reverse faulting and a $10-20^{\circ}$ westward rotation of the direction of maximum horizontal compression. These models suggest that the stress orientation and fault geometry allowed the right-lateral oblique motion on the Susitna Glacier fault to trigger the resulting rupture on the Denali fault.

\section{Acknowledgments}

We thank Jeanne Hardebeck for guidance in interpreting stress orientations from focal mechanism inversions and analyzing our preferred stress orientations with the focal mechanism data. We also benefited from helpful discussions with Chen Ji and Douglas Dreger regarding their kinematic source inversions for this earthquake and thank Peter Hauessler for providing the locations of the surface rupture. We appreciated helpful reviews from Ruth Harris, David Oglesby, Paul Spudich, and an anonymous reviewer. The simulations were run on the Hewlett-Packard V-Class computer, located at the California Institute of Technology, with access provided by the Center for Advanced Computing Research. Some of the plots were created using the Generic Mapping Tools (GMT) (Wessel and Smith, 1998).

\section{References}

Aagaard, B. T. (1999). Finite-element simulations of earthquakes. Technical Report 99-03, California Institute of Technology, Earthquake Engineering Research Laboratory, Pasadena, California.

Aagaard, B. T., T. H. Heaton, and J. F. Hall (2001). Dynamic earthquake ruptures in the presence of lithostatic normal stresses: Implications for friction models and heat production, Bull. Seism. Soc. Am. 91, no. $6,1765-1796$.

Anderson, G., B. Aagaard, and K. Hudnut (2003). Fault interactions and large complex earthquakes in the Los Angeles area, Science 302, no. 5652, 1946-1949.

Andrews, D. J. (1976). Rupture velocity of plane strain shear cracks, J. Geophys. Res. 81, no. 32, 5679-5687.

Aochi, H., and E. Fukuyama (2002). Three-dimensional nonplanar simulation of the 1992 Landers earthquake, J. Geophys. Res. Solid Earth 107, no. B2, 2035, doi 10.1029/2000JB000061.

Aochi, H., E. Fukuyama, and M. Matsu'ura (2000). Spontaneous rupture propagation on a non-planar fault in 3-D elastic medium, Pure Appl. Geophys. 157, no. 11-12, 2003-2027.

Archuleta, R. J. (1984). A faulting model for the 1979 Imperial-Valley earthquake, J. Geophys. Res. Solid Earth 89, no. B6, 4559-4585.

Bassin, C., G. Laske, and G. Masters (2000). The current limits of resolution for surface wave tomography in North America, EOS Trans. 81, 897.

Bayarsayhan, C., A. Bayasgalan, B. Enhtuvshin, K. W. Hudnut, R. A. Kurushin, P. Molnar, and M. Olziybat (1996). 1957 Gobi-Altay, Mongolia, earthquake as a prototype for southern California's most devastating earthquake, Geology 24, no. 7, 579-582.

Das, S., and K. Aki (1977). A numerical study of two-dimensional spontaneous rupture propagation, Geophys. J. R. Astr. Soc. 50, no. 3, 643668.

Day, S. M. (1982). Three-dimensional finite-difference simulation of fault dynamics: rectangular faults with fixed rupture velocity, Bull. Seism. Soc. Am. 72, no. 3, 705-727.

Doser, D. I. (2004). Seismicity of the Denali-Totschunda fault zone in Central Alaska (1912-1988) and its relation to the 2002 Denali fault earthquake sequence, Bull. Seism. Soc. Am. 94, no. 6B, S132-S144. 
Dreger, D. S., D. D. Oglesby, R. A. Harris, N. Ratchkovski, and R. Hansen (2004). Kinematic and dynamic rupture models of the November 3, $2002 M_{\mathrm{w}} 7.9$ Denali, Alaska, earthquake, Geophys. Res. Lett. 31, no. 4, L04605, doi 10.1029/2003GL018333.

Eberhart-Phillips, D., P. J. Haeussler, J. T. Freymueller, A. D. Frankel, C. M. Rubin, P. Craw, N. A. Ratchkovski, G. Anderson, G. A. Carver, A. J. Crone, T. E. Dawson, H. Fletcher, R. Hansen, E. L. Harp, R. A. Harris, D. P. Hill, S. Hreinsdottir, R. W. Jibson, R. Jones, L. M. Kayen, D. K. Keefer, C. F. Larsen, S. C. Moran, S. F. Personius, G. Plafker, B. Sherrod, K. Sieh, N. Sitar, and W. K. Wallace (2003). The 2002 Denali fault earthquake, Alaska: a large magnitude, slippartitioned event, Science 300, no. 5622, 1113-1118.

Florensov, N. A., and V. P. Solonenko (Editors) (1965). The Gobi-Altay Earthquake, U.S. Department of Commerce, Washington, D.C., $424 \mathrm{pp}$.

Guatteri, M., and P. Spudich (2000). What can strong-motion data tell us about slip-weakening fault-friction laws? Bull. Seism. Soc. Am. 90, no. $1,98-116$.

Harris, R. A., and S. M. Day (1993). Dynamics of fault interaction: parallel strike-slip faults, J. Geophys. Res. Solid Earth 98, no. B3, 4461-4472.

Harris, R. A., and S. M. Day (1999). Dynamic 3-D simulations of earthquakes on en echelon faults, Geophys. Res. Lett. 26, no. 14, 20892092.

Harris, R. A., R. J. Archuleta, and S. M. Day (1991). Fault steps and the dynamic rupture process: 2-D numerical simulations of a spontaneously propagating shear fracture, Geophys. Res. Lett. 18, no. 5, 893896.

Harris, R. A., J. F. Dolan, R. Hartleb, and S. M. Day (2002). The 1999 Izmit, Turkey, earthquake: a 3D dynamic stress transfer model of intraearthquake triggering, Bull. Seism. Soc. Am. 92, no. 1, 245-255.

Heaton, T. H. (1990). Evidence for and implications of self-healing pulses of slip in earthquake rupture, Phys. Earth Planet. Interiors 64, no. 1, $1-20$.

Johnson, A. M., R. W. Fleming, and K. M. Cruikshank (1994). Shear zones formed along long, straight traces of fault zones during the 28 June 1992 Landers, California, earthquake, Bull. Seism. Soc. Am. 84, no. 3, 499-510.

Kame, N., J. R. Rice, and R. Dmowska (2003). Effects of prestress state and rupture velocity on dynamic fault branching, J. Geophys. Res. Solid Earth 108, no. B5, 2265, doi 10.1029/2002JB002189.

Kase, Y., and K. Kuge (1998). Numerical simulation of spontaneous rupture processes on two non-coplanar faults: the effect of geometry on fault interaction, Geophys. J. Int. 135, no. 3, 911-922.

Kase, Y., and K. Kuge (2001). Rupture propagation beyond fault discontinuities: significance of fault strike and location, Geophys. J. Int. 147, no. 2, 330-342.

Kurushin, R. A., A. Bayasgalan, M. Olziybat, B. Enhtuvshin, P. Molnar, C. Bayarsayhan, K. W. Hudnut, and J. Lin (1997). The surface rupture of the 1957 Gobi-Altay, Mongolia, earthquake, Geol. Soc. Am. Special Paper 320, Geological Society of America, Boulder, Colorado.

Lettis, W., J. Bachhuber, R. Witter, C. Brankman, C. E. Randolph, A Barka, W. D. Page, and A. Kaya (2002). Influence of releasing stepovers on surface fault rupture and fault segmentation: examples from the 17 August 1999 Izmit earthquake on the North Anatolian fault, Turkey, Bull. Seism. Soc. Am. 92, no. 1, 19-42.
Madariaga, R., and A. Cochard (1994). Seismic source dynamics, heterogeneity and friction, Ann. Geofis. 37, no. 6, 1349-1375.

Madariaga, R., and K. B. Olsen (2000). Criticality of rupture dynamics in 3-D, Pure App. Geophys. 157, no. 11-12, 1981-2001.

Oglesby, D. D., S. M. Day, and D. R. H. O'Connell (2003a). Dynamic and static interaction of two thrust faults: a case study with general implications, J. Geophys. Res. Solid Earth 108, no. B10, 2489, doi 10.1029/2002JB002228.

Oglesby, D. D., S. M. Day, Y.-G. Li, and J. E. Vidale (2003b). The 1999 Hector Mine earthquake: the dynamics of a branched fault system, Bull. Seism. Soc. Am. 93, no. 6, 2459-2476.

Olsen, K. B., R. Madariaga, and R. J. Archuleta (1997). Three-dimensional dynamic simulation of the 1992 Landers earthquake, Science 278, 834-839.

Poliakov, A. N. B., R. Dmowska, and J. R. Rice (2002). Dynamic shear rupture interactions with fault bends and off-axis secondary faulting, J. Geophys. Res. Solid Earth 107, no. B11, 2295, doi 10.1029/ 2001 JB000572.

Prentice, C. S., K. Kendrick, K. Berryman, A. Bayasgalan, J. F. Ritz, and J. Q. Spencer (2002). Prehistoric ruptures of the Gurvan Bulag fault, Gobi Altay, Mongolia, J. Geophys. Res. Solid Earth 107, no. B12, 2321, doi 10.1029/2001JB000803.

Ratchkovski, N. A. (2003). Change in stress directions along the central Denali fault, Alaska after the 2002 earthquake sequence, Geophys. Res. Lett. 30, no. 19, 2017, doi 10.1029/2003GL017905.

Rice, J. R. (1993). Spatiotemporal complexity of slip on a fault, J. Geophys. Res. Solid Earth 98, no. B6, 9885-9907.

Sowers, J. M., J. R. Unruh, W. R. Lettis, and T. D. Rubin (1994). Relationship of the Kickapoo fault to the Johnson Valley and Homestead Valley faults, San-Bernardino County, California, Bull. Seism. Soc. Am. 84, no. 3, 528-536.

Treiman, J. A., K. J. Kendrick, W. A. Bryant, T. K. Rockwell, and S. F. McGill (2002). Primary surface rupture associated with the $M_{\mathrm{w}} 7.1$ 16 October 1999 Hector Mine earthquake, San Bernardino County, California, Bull. Seism. Soc. Am. 92, no. 4, 1171-1191.

Wessel, P., and W. H. F. Smith (1998). New, improved version of the generic mapping tools released, EOS Trans. 79, 579.

U.S. Geological Survey

MS 977

345 Middlefield Rd.

Menlo Park, California 94025

(B.T.A.)

UNAVCO, Inc.

6350 Nautilus Drive

Boulder, Colorado 80301

(G.A.)

U.S. Geological Survey

525 South Wilson Ave.

Pasadena, California 91106

(K.W.H.)

Manuscript received 3 February 2004. 